Вакуленко Олеся Михайлівна, доцент кафедри бальної хореографії, Київський національний університет культури і мистецтв, https://orcid.org/0000-0002-7906-4626 vakusia@gmail.com

\title{
НОВАТОРСТВО СЦЕНІЧНИХ БАЛЬНИХ ТАНЦІВ ПОЧАТКУ ХХI ст.
}

\begin{abstract}
Мета статті - виявити та охарактеризувати тенденції збагачення хореографічної мови та пошуки нових виражальних засобів у сучасній сценічній бальній хореографії. Методи дослідження. Застосовано культурноісторичний метод (для розгляду та осмислення проблематики сценічних бальних танців у контексті специфіки культуротворчих процесів початку XXI ст.); метод філософського аналізу хореографічної лексики сценічного бального танцю та новаторських засобів хореографічної виразності; метод структурно-функціонального аналізу (для структурування характерних явищ сучасної сценічної бальної хореографії та встановлення взаємозв'язків між ними). Наукова новизна. Теоретично осмислено проблеми новаторських виражальних засобів сценічного бального танцю шляхом аналізу творчого пошуку хореографічної мови провідних світових балетмейстерів-постановників початку XXI ст. Виявлено причини, специфіку та закономірності виникнення і розвитку нових виражальних засобів у постановках сучасної сценічної бальної хореографії. Висновки. Внаслідок аналізу новаторських пошуків сценічного бального танцю початку XXI ст. виявлено, що характерною тенденцією сучасних хореографів-постановників $\epsilon$ прагнення до втілення танцюристом психологічно- та філософсько-осмисленого образу, розкриття засобами хореографічної виразності внутрішнього світу людини. Музичний супровід хореографічної вистави створює атмосферу, що виражає задум постановника та $\epsilon$ підгрунтям для визначення виражальних засобів. Танцювальна лексика сучасної сценічної бальної хореографії сублімує елементи класики, модерну, стилізацію етнічного танцю та натуралістичні побутові жести; характеризується збагаченням бального танцю новими пластичними інтонаціями. Новаторством хореографії є звернення постановників до складних танцювальних форм, значне посилення образності та виразності, спрямування до сприйняття та осмислення пластичної мови.
\end{abstract}

Ключові слова: сценічна бальна хореографія, хореографічна мова, новаторство, виражальні засоби, хореографічна вистава.

Вакуленко Олеся Михайловна, доиент кафедры бальной хореографии, Киевский наииональный университет культуры и искусств

\section{Новаторство сценических бальных танцев начала XXI века}

Цель статьи - выявить и охарактеризовать тенденции обогащения хореографической языка и поиски новых выразительных средств в современной сценической бальной хореографии. Методы исследования. Применен культурно-исторический метод (для рассмотрения и осмысления проблематики сценических бальных танцев в контексте специфики культуротворчих процессов начала XXI в.); метод философского анализа хореографической лексики сценического бального танца и новаторских средств хореографической выразительности; метод структурнофункционального анализа (для структурирования характерных явлений современной сценической бальной хореографии и установления взаимосвязей между ними). Научная новизна. Теоретически осмысленно проблемы новаторских выразительных средств сценического бального танца путем анализа творческого поиска хореографического языка ведущих мировых балетмейстеров-постановщиков начала XXI века. Выявлены причины, специфика и закономерности возникновения и развития новых выразительных средств в постановках современной сценической бальной хореографии. Выводы. Вследствие анализа новаторских поисков сценического бального танца начала XXI века выявлено, что характерной тенденцией современных хореографов-постановщиков есть стремление к воплощению танцором психологично- и философско-осмысленного образа, раскрытие средствами хореографического выразительности внутреннего мира человека. Музыкальное сопровождение хореографического спектакля создает атмосферу, выражает замысел постановщика и является основой для определения выразительных средств. Танцевальная лексика современного сценического бальной хореографии сублимирует элементы классики, модерна, стилизацию этнического танца и натуралистические бытовые жесты; характеризуется обогащением бального танца новыми пластическими интонациями. Новаторством хореографии является обращение постановщиков к сложным танцевальным формам, значительное усиление образности и выразительности, направление к восприятию и осмыслению пластического языка.

Ключевые слова: сценическая бальная хореография, хореографический язык, новаторство, выразительные средства, хореографическое представление.

(C) Вакуленко О.М., 2019 
Vakulenko Olesya, Associate Professor of the Ballroom Choreography Department at the Kiev National University of Culture and Arts, Kiev, Ukraine

Innovation of stage ballroom dancing at the beginning of the XXI century

The purpose of the article is to identify and characterize the trends in enrichment of the choreographic language and the search for new expressive means in modern stage ballroom choreography. Methodology. The cultural-historical method has been applied (to consider and comprehend the problems of stage ballroom dancing in the context of the specifics of cultural processes at the beginning of the 21st century); a method of philosophical analysis of the choreographic vocabulary of stage ballroom dance and innovative means of choreographic expression; method of structural and functional analysis (for structuring the characteristic phenomena of modern stage ballroom choreography and establishing relationships between them). Scientific novelty. The problems of innovative expressive means of stage ballroom are theoretically meaningful by analyzing the creative search for the choreographic language of the world's leading choreographers of the beginning of the 21st century. The causes, specificity and patterns of the emergence and development of new expressive means in the productions of modern stage ballroom choreography are revealed. Conclusions. As a result of the analysis of the innovative search for stage ballroom dance at the beginning of the $21 \mathrm{st}$ century, it has been revealed that the characteristic tendency of modern choreographers is the desire for the dancer to embody a psychologically and philosophically meaningful image, to reveal by means of the choreographic expressiveness of the person's inner world. The musical accompaniment of the choreographic performance creates an atmosphere, expresses the director's intention and is the basis for determining expressive means. Dance vocabulary of modern stage ballroom choreography sublimates elements of classics, modernism, stylization of ethnic dance and naturalistic everyday gestures; characterized by the enrichment of ballroom dance with new plastic intonations. The innovation of choreography is the appeal of directors to complex dance forms, a significant increase in imagery and expressiveness, a direction towards the perception and understanding of plastic language.

Key words: stage ballroom choreography, choreographic language, innovation, expressive means, choreographic performance.

Актуальність теми дослідження. На сучасному етапі в світовій сценічній практиці активізувалися експерименти та пошук нових засобів проникнення в глибини людської підсвідомості. Експериментальні пошуки хореографів-постановників зумовлені формуванням нової художньої мови та засобів виразності, що відповідає рівню розвитку світової сценічної хореографії початку XXI ст., індивідуальному творчому баченню та запитам сучасного глядача. Основним завданням сценічного бального танцю стає визначення відповідності між новаторськими засобами та ефективністю їх художнього впливу, що у свою чергу активізує наукове осмислення даного питання.

Мета статті - виявити та охарактеризувати тенденції збагачення хореографічної мови та пошуки нових виражальних засобів у сучасній сценічній бальній хореографії.

Аналіз джерел засвідчив, що проблематика сучасної сценічної бальної хореографії наразі лишається недостатньо висвітленою у вітчизняному науковому вимірі. Зокрема, питання творчого пошуку і новаторства сценічного бального танцю досліджує А. Голубенков у публікації «Синтез в мистецтві сценічної хореографії» [1]; особливості естетичного сприйняття постановок сценічної бальної хореографії у контексті дослідження драматургії як художнього методу створення та подачі змістової форми сучасної сценічної хореографічної постановки, а також тенденції і перспективи еволюціонування драматургії сценічного бального танцю аналізує А. Крись в наукових статтях «Специфіка естетичного сприйняття сценічної бальної хореографії» [5] та «Тенденції розвитку драматургії сценічної бальної хореографії у контексті світових процесів» [6].

У даній статті новаторство сучасної сценічної бальної хореографії досліджено у контексті збагачення лексики бального танцю та хореографічних засобів виразності.

Виклад основного матеріалу. Розвиток хореографічного мистецтва залежить від відкриттів та інновацій, отриманих в результаті творчого пошуку. Відповідно творчість позиціонується не лише як вираження потенціалу хореографа, але й як основа еволюціонування. На думку дослідників, творчість та новаторство - взаємопов'язані поняття, оскільки новаторство включає два етапи: етап творчості (генерація нових ідей) та етап реалізації (послідовність творчих ідей) [7, 240].

Однією з провідних тенденцій сценічної бальної хореографії початку XXI ст. є збагачення лексики бального танцю шляхом синтезування та інтегрування елементів класичного, характерного та сучасного танцю - подібна практика наразі є базовою в багатьох хореографічних колективах.

Танець наділений специфічним способом художньої рефлексії, в межах якої засобами ритмопластики організованих у проторі та часі рухів тіла створюється особливий тип художньої мови [4, 9-10]. На думку Ю. Кондратенка, процес функціонування художньої мови танцю - динамічна система взаємодії зовнішніх та внутрішніх рівнів іiі структури, на кожному з яких відбувається процес сенсоутворення, зумовлений художнім мисленням та рефлексивним досвідом, а також процеси формотворення, пов’язані 3 втіленням та вираженням сенсу. 
Варто зазначити, що збагачення хореографічної мови бального танцю шляхом інтегрування елементів етнічного, класичного та сучасного танцю (сценічного та соціального), тобто міжжанровий синтез, є художнім методом постановників Севастопольського академічного театру танців ім. В. Єлізарова. Аналізуючи виставу «Бродвей» (авторська хореографія В. Єлізарова, прем'єра в 2011 р.), що позиціонована як художня репрезентація жанру мюзикл, дослідники акцентують на використанні постановником багаторівневого синтезу, не обмеженого «поелементним поєднанням різних танцювальних стилів та технік» [1].

На думку дослідників, міжжанровий синтез забезпечує високу актуальність сучасного хореографічного мистецтва, що пояснюється кореляцією з глобальними соціальними та культурними процесами. Створені внаслідок використання даного новаторського підходу хореографічні постановки об’єктивно передають складну художню картину сучасного світу $[2,178]$. А. Голубенков стверджує, що міжжанровий синтез дозволяє створювати оригінальні сценічні постановки, 3 метою задоволення візуальних та пізнавальних потреб (знайомство 3 іншими культурами, осмислення їх цінності та глибинності задумів) сучасного глядача [1].

Одним із напрямів інноваційних процесів соціомистецького простору початку XXI ст., що найяскравіше виявляється в хореографії, як стверджує Н. Карчевська, є нетрадиціоналізм, у контексті звернення до історично сформованих класичних форм, що на відміну від авангардно-модерністських взірців складають шар відносно нової художньої традиції в мистецтві [3, 102]. Дана тенденція проявляється на рівні використання постановниками певних художніх прийомів, зокрема універсалізації принципу цитування.

Синтетизм сценічної хореографії гармонізує процес поєднання бальної та етнічної танцювальної лексики шляхом:

- використання постановником відповідного музичного матеріалу та костюму (або їх характерних елементів);

- завдяки безпосередньому цитуванню пластичних елементів танцювального фольклору;

- шляхом застосування відповідних режисерських прийомів, наприклад, трансформування елементів ритуально-обрядової практики у перформанс.

Органічність інтегрування залежить від умови відповідності обраних елементів етнічного танцю основним принципам побудови лексики бального танцю, оскільки саме він виконує асимілюючу функцію.

Зауважимо, що органічність поєднання, а відповідно й художній ефект сценічної постановки безпосередньо залежить від жанрової приналежності вистави та змістово-сенсового аспекту.

На сучасному етапі у постановках сценічної бальної хореографії високий рівень володіння виконавцем пластичною культурою тіла означає передусім привнесення в нього внутрішнього, ідейнообразного початку.

Видовищність сценічного бально танцю зумовлена раціональним використанням різноманітних засобів виразності, за допомогою яких створюється неповторний музично-художній образ.

Хореографічні засоби виразності це:

- тип побудови вистави (дивертисмент, колаж, ліричні картини, наскрізний симфонічний розвиток та ін.);

- хореографічний текст, що складається з сольних, парних та ансамблевих форм різних видів танцю та танцювальних характеристик;

- взаємодія хореографічних та музичних форм;

- вибір теми, ідеї, сюжету хореографічної вистави;

- постановочні прийоми (способи вирішення хореографічних образів, їх філософський сенс, роль аксесуарів та предметів у постановці, сценографії та ін.).

Специфіка засобів виразності сценічної бальної хореографії зумовлена естетикою бального танцю (визначається ступенем хореографічної підготовки, що забезпечує формування високої культури рухів, статичної та динамічної осанки, засвоєнням високохудожніх статичних та динамічних жестів, поз та міміки), відмінною характеристикою якої $\epsilon$ артистичність та пластичність рухів, відповідність спрямованості та змісту музичного твору формі та змісту моторних актів, що складають виступ танцюристів.

Відповідно можемо позиціонувати засоби хореографічної виразності сценічного бального танцю як поняття, що включає сукупність засобів сценічної виразності - пластичних ідей (лексика), музичної ідеї, сценографічної ідеї, індивідуальності танцюристів та специфіці творчого бачення хореографапостановника. 
Новаторство змістового аспекту сценічної бальної хореографії початку XXI ст. полягає в оригінальній формі міжвидового та міжжанрового взаємозв'язку, що характеризується великим розмаїттям ритмів, зумовлюючи прояв творчої індивідуальності постановника та танцюристів, здатності до унікального сприйняття зовнішнього середовища шляхом рухової та музичної інтерпретації ритмів.

Індивідуальний підхід до постановки танцювальної вистави у контексті сценічної бальної хореографії проявляється передусім у специфіці формування авторського стилю, що базується на відчутті відповідності рухів бальних танців музичному супроводу, емоційному стану постановки та світосприйнятті хореографа.

Новаторство в процесі розробки композиції вистави зумовлено творчим початком сценічного бального танцю, що передбачає сублімування натхнення, уявлення та домінування імпровізаційності, за допомогою якого постановник може розширити межі сучасного сценічного простору, традицій, загальноприйнятих стандартів.

Наукова новизна. Теоретично осмислено проблеми новаторських виражальних засобів сценічного бального танцю шляхом аналізу творчого пошуку хореографічної мови провідних світових балетмейстерів-постановників початку XXI ст. Виявлено причини, специфіку та закономірності виникнення і розвитку нових виражальних засобів у постановках сучасної сценічної бальної хореографії.

Висновки. Внаслідок аналізу новаторських пошуків сценічного бального танцю початку XXI ст. виявлено, що характерною тенденцією сучасних хореографів-постановників $\epsilon$ прагнення до втілення танцюристом психологічно- та філософсько-осмисленого образу, розкриття засобами хореографічної виразності внутрішнього світу людини. Музичний супровід хореографічної вистави створює атмосферу, що виражає задум постановника та $є$ підгрунтям для визначення виражальних засобів. Танцювальна лексика сучасної сценічної бальної хореографії сублімує елементи класики, модерну, стилізацію етнічного танцю та натуралістичні побутові жести; характеризується збагаченням бального танцю новими пластичними інтонаціями. Новаторством хореографії є звернення постановників до складних танцювальних форм, значне посилення образності та виразності, спрямування до сприйняття та осмислення пластичної мови.

\section{Jimepamypa}

1. Голубенков А. Синтез в искусстве сценической хореографи. URL : http://intkonf.org/golubenkov-a-gsintez-v-iskusstve-stsenicheskoy-horeografii (дата зверенння 21.08. 2019).

2. Карчевская Н. В. Межжанровый синтез и эклектика в хореографическом искусстве. Навуковы пошук у сферы сучаснай культуры i мастацтва: інавацыйныя падыходы : матэрыялы навуковай канферэнцыі прафесарска-выкладчыцкага складу, прысвечанай 40-годдзю заснавання Беларускага дзяржаўнага ўніверсітэта культуры і мастацтваў (Мінск, 25 лістапада 2015 г.) / Беларускі дзяржаўны ўніверсітэт культуры і мастацтваў. Мінск, 2017. С. 174-178.

3. Карчевская Н. В. Проблемы синтеза традиций и новаций в современном хореографическом искусстве Беларуси. Культура. Наука. Творчество : сб. научн. статей. Минск, 2014. С. 101-104.

4. Кондратенко Ю. А. Система художественного языка танца: специфика, структура и функционирование : автореферат дис. доктора искусствоведения : 24.00.01 / Мордовский государственный университет им Н. П. Огарева. Саранск, 2010. 36 с.

5. Крись А. Специфіка естетичного сприйняття сценічної бальної хореографії. Вісник КНУКіМ. Серія мистецтвознавство. 2019. № 40. C. 161-166. DOI: https://doi.org/10.31866/2410-1176.40.2019.172697.

6. Крись А. С. Тенденції розвитку драматургії сценічної бальної хореографії у контексті світових процесів. Мистецтвознавчі записки. 2019. Вип. 35. 189-195.

7. Nakano T. C., Wechsler S. M. Creativity and innovation: Skills for the 21st Century. Estudos de Psicologia (Campinas). 2018. № 35(3). pp. 237-246. http://dx.doi.org/10.1590/1982-02752018000300002.

\section{References}

1. Golubenkov, A. Synthesis in the art of stage choreography. Available at : http://intkonf.org/golubenkov-a-gsintez-v-iskusstve-stsenicheskoy-horeografii. [in Russian].

2. Karchevskaya, N. V. (2017). Intergenre synthesis and eclecticism in choreographic art. Scientific research in the field of contemporary culture and art: Innovative Approaches: Materials of scientific conference of the faculty, dedicated to the 40th anniversary of the Belarusian State University of Culture and Arts (Minsk, 25 November 2015). Belarusian State University of Culture and Arts. Minsk, pp. 174-178 [in Russian]. 